\title{
Chemical profile colostrum, quality refrigerated and frozen milk of santa inês sheep
}

\author{
João Antônio Gonçalves e Silva $^{1}$ (D) Mariana da Mata Silveira ${ }^{1}$ (i) Paulo Victor Toledo Leão (D) $^{1}$

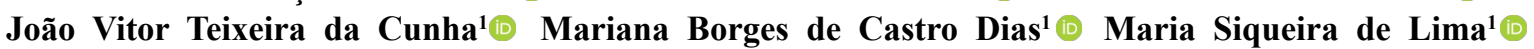 \\ Ruthele Moraes do Carmo $^{2}$ (i) Karen Martins Leão ${ }^{1}$ (i) Elis Aparecido Bento ${ }^{1}$ (i) \\ Edmar Soares Nicolau ${ }^{2}$ (i) Marco Antônio Pereira da Silva ${ }^{1^{*}}$ (1)
}

${ }^{1}$ Instituto Federal Goiano, Campus Rio Verde, 75901-970, Rio Verde, GO, Brasil.

${ }^{2}$ Universidade Federal de Goiás (UFG), Campus Samambaia, Chácaras de Recreio Samambaia, Goiânia, GO, Brasil. E-mail: marco.antonio@ifgoiano.edu.br. *Corresponding author.

ABSTRACT: The chemical composition of Santa Inês sheep colostrum was evaluated, as well as chilled milk (zero to 240 hours) and frozen milk for up to 70 days. Results of chemical composition (fat, protein, casein, lactose, total and degreased dry extract) and colostrum somatic cell count (SCC) were presented descriptively. The results of chemical composition and SCC and total bacterial count (TBC) of chilled and frozen milk were evaluated in a completely randomized design, the repetition of milk collection days and the treatments of the times when the milk was chilled and frozen. The comparison of the quality averages of chilled and frozen milk was performed by Tukey test, with a probability of $5.0 \%$. Santa Inês sheep colostrum showed high protein and fat content, demonstrating a high source of nutrients for lamb nutrition. Santa Inês sheep's milk can be stored for up to 240 hours without changes in chemical quality. Frozen milk from Santa Inês ewes for up to 70 days minus fat content; however, this form of milk preservation is viable. Refrigeration and freezing are alternatives that add value to the milk of Santa Ines ewes, but studies with previous preservation methods are necessary for greater quality assurance.

Key words: conservation methods, fat content, ovis aries, protein value.

Perfil químico do colostro, qualidade do leite refrigerado e congelado de ovelhas santa inês

RESUMO: Avaliou-se a composição química do colostro de ovinos Santa Inês, leite refrigerado (zero a 240 horas) e leite congelado por até 70 dias. Os resultados de composição química (gordura, proteína, caseína, lactose, extrato seco total e desengordurado) e contagem de células somáticas do colostro (CCS) foram apresentados de forma descritiva. Os resultados da composição química, CCS e da contagem bacteriana total (CBT) do leite refrigerado e congelado foram avaliados em delineamento inteiramente casualizado. As repetições foram os dias de coleta do leite e os tratamentos os tempos em que o leite foi refrigerado e congelado. A comparação das médias de qualidade do leite resfriado e congelado foi realizada pelo teste de Tukey, com probabilidade de 5,0\%. O colostro de ovinos Santa Inês apresentou alto teor de proteina e gordura, demonstrando ser uma grande fonte de nutrientes para a nutrição de cordeiros. O leite de ovelha Santa Inês pode ser armazenado sob refrigeração por até 240 horas sem alterações da composição química. O leite congelado de ovelhas Santa Inês pode ser armazenado por até 70 dias, contudo ocorre alteração da composição química, principalmente nos teores de gordura. A refrigeração e o congelamento são alternativas que agregam valor ao leite de ovelhas Santa Inês, porém, mais estudos com estes métodos de preservação, são necessários para maior garantia de qualidade.

\section{INTRODUCTION}

Santa Inês sheep is a breed from crossbreeding of Bergamácia, Morada Nova, Somalis and other native breed sheep no defined (VERÍSSIMO et al., 2009), without wool and with great variation of coat (REGO NETO, 2003). They are characterized for being a large size, fast growth and good milk production, providing good conditions for the lambs birth (BARROS et al., 2004).

The use of dairy sheep enables the production of dairy products with high nutritional value and that have a high financial added value. There is a little research about dairy production performance of Santa Inês sheep; however, studies about this indicated a great potencial milk because this breed have genetics of Bergamácia that is a great milk production breed (FERREIRA et al., 2011).

After birth, the first secretion of the mammary glands is called colostrum (PATTINSON et al., 1995), providing immunity passive, contributes to the development of digestive system, affecting the endocrine and metabolic systems, being energy source for young animals to obtain generation of heat therapy 
against hypothermia (RAUPRICH et al., 2000). However, information about colostrum composition are limited (HADJIPANAYIOTOU, 1995), mainly of Santa Inês sheep.

Ewes' milk, in addition to high solids concentration (MCKUSICK et al.2002), has high levels of fat and casein, an important factor in the soft and stiff cheeses, with particular characteristics of texture and flavor and with high market value (MOHAPATRA et al., 2019), become good for industry processing (BOYAZOGLU \& MORAND-FEHR, 2001).

The milk refrigeration preserves the first quality after use. Thus, the implementation of refrigeration has brought advantages to the milk producer and cheese industry (ALAIS, 1985). But, when refrigeration is for long periods, new hygienic problems arise, because of the selection of the psychrotrophic microorganisms (MIRANDA \& GRIPON, 1986).

Frozen milk for cheeses production can be an alternative to solve the seasonality of dairy production (KATILI et al., 2006), because this process just slows the growth of the microbial population activity in the milk (PORCIONATO et al., 2008).

On this, this study evaluated the chemical characteristics of Santa Inês colostrum and the effect of different cooling and freezing times on the quality milk.

\section{MATERIALS AND METHODS}

Were used eight ewes Santa Inês breed with weight of $\pm 60.0 \mathrm{~kg}$ and 3.5 years average age with access to Brachiaria Brizantha pasture, mineral salt and water $a d$ libitum. Milking was done manually once a day in the morning. In the afternoon, one day before the milking the lambs were separated of the ewes. For milking was used gloves by the milker and was realized the before dipping iodine solution $(5.0 \%)$. At the end of the milking, the lambs were together with the sheep. Before the analysis, colostrum and milked milk were filtered.

\section{Physical-chemical colostrum quality}

Colostrum samples were collected from eight Santa Inês sheep from the first day until fourth day postpartum, was evaluated eight samples per day. Colostrum was packaged in $40 \mathrm{~mL}$ sterilized bottles containing Bronopol ${ }^{\circledR}$ preservative, the samples were identified and sent to the laboratory for chemical and SSC analysis. Results of the chemical analysis and colostrum were evaluated description in Excel ${ }^{\circledR} 2007$ software.

\section{Quality of refrigerated milk}

The milk samples were evaluated after zero hours, 24 hours, 48 hours, 72 hours, 96 hours,
120 hours, 144 hours, 168 hours, 192 hours, 216 hours and 240 hours of totaling 11 ways of analysis. After milking, the milk was distributed in sterilized $40 \mathrm{~mL}$ according to established treatments stored in B.O.D. (Biochemical Oxygen Demand) model LIMATEC $^{\circledR}$ LT 320 TFP-II at $4.0^{\circ} \mathrm{C}$. This process was repeated for three consecutive days to be used like repetitions. The experiment was performed in DIC with three replicates and 11 treatments, the variables analyzed were compared using the Tukey test to $5.0 \%$ probability in the statistical software Sisvar 5.6 (FERREIRA, 2015).

\section{Frozen milk quality \\ The milk samples were analyzed after zero,} 14, 28, 42, 56 and 70 days of freezing. After milking the milk samples were distributed in sterilized bottles of $40 \mathrm{~mL}$ capacity, stored in a freezer at $-18{ }^{\circ} \mathrm{C}$. The milking was carried out by three consecutive days for the repetitions to be constituted.

The samples of each treatments passed through the thaw, one day before the corresponding evaluation time, in B.O.D in temperature of $4.0^{\circ} \mathrm{C}$. The Bronopol ${ }^{\circledR}$ and Azidiol ${ }^{\circledR}$ preservatives were added to the chemical analysis, SCC and TBC, respectively, in the exact moments of evaluation.

The experiment was performed in DIC with three replicates and six treatments, the mean values were compared using the Tukey test at 5.0 $\%$ probability in the statistical program Sisvar 5.6 (FERREIRA, 2015).

\section{Electronic milk analysis}

For electronic milk analysis the samples were packed in a box with ice and sent to the Laboratory for analysis the chemical composition (fat, protein, lactose, total dry extract (TDE), defatted dry extract (DDE) and casein), SCC and TBC.

The fat concentration, protein, lactose, defatted dry extract (DDE) and TDE, through the analytical principle based on the differential absorption of infrared waves by the milk components, using Milkoscan 4000 equipment (Foss Electric A / $\mathrm{S}$, Hillerod, Denmark). The samples were previously heated in a water bath at a temperature of $40^{\circ} \mathrm{C}$ for 15 min., for dissolving the fat. Results were expressed as percentage (\%) (INTERNATIONAL DAIRY FEDERATION, 2013).

The Casein was determined by the analytical principle based on the differential absorption of infrared waves transformed by Fourier - FTIR, using the Lactoscope equipment (Delta instruments). The casein results were expressed in percentage (\%). 
The SCC analysis was carried out in accordance with the analytical principle flow cytometry performed using the Fossomatic 5000 Basic equipment (Foss Electric A/S. Hillerod, Denmark). Before to analysis, the samples were previously heated in a water bath at $40{ }^{\circ} \mathrm{C}$ for 15 minutes to dissolve the fat. The results were expressed in SCC per mL (IDF, 2006). The TBC was analyzed using the Bactoscan FC equipment (Foss Eletric A/S. Hillerod, Denmark), which is based on flow cytometry consisting of the measurement of cell characteristics when they are suspended in fluid. Results were expressed in CFU per mL (INTERNATIONAL DAIRY FEDERATION, 2013).

\section{RESULTS AND DISCUSSION}

Santa Inês sheep colostrum presented great total solids concentration (Table 1). The results of fat, protein, lactose and DDE from this research were different from those observed by ALVES et al. (2015) in the composition of sheep colostrum Santa Inês (primiparous and multiparous), the values were of 7.32 $\%$ and $7.43 \%$ of fat, protein of $8.78 \%$ and $8.24 \%$, lactose of $4.17 \%$ and $4.20 \%$ and DDE of $14.09 \%$ and $13.69 \%$; respectively, showing that the birth order influences the physico-chemical properties of colostrum, in addition, the chemical milk composition can diversify due to climatic conditions and feeding (SOUZA et al., 2005).

Results that corroborated the great nutrient concentration of colostrum sheep from this study, were also reported by HERNÁNDEZ-CASTELLANO et al. (2016) comparing the chemical composition of ovine colostrum with respect to bovine animals, values were $9.94 \%$ and $6.60 \%$, protein of $13.94 \%$ and $11.65 \%$, lactose of $2.33 \%$ and $1.86 \%$ and total solids of 26.76 $\%$ and $16.07 \%$.

The results of colostrum from Santa Inês sheep were different compared to the study of KUMAR et al. (2017) when evaluating the chemical composition of colostrum from Mapura and Malwari sheep, the authors observed $7.70 \%$ and $7.10 \%$ fat, 7.90 $\%$ and $7.70 \%$ protein and $17.6 \%$ and $16.8 \%$ TDE, respectively. The physical-chemical composition of colostrum and milk may vary according to breed and fitness, influencing the form of management adopted.

The colostrum was collected until the 4th day postpartum; and therefore, it was possible to verify values for fat, lactose and different for protein and TDE of the study performed by HADJIPANAYIOTOU (1995), who evaluated the composition of colostrum and milk and observed that there is a fall in the percentage of fat, protein and TDE in ovine colostrum from the first postpartum day to the fourth day, with fat (day $1-11.0 \%$, day $11-6.0 \%$ ), protein had a gradual decrease of the values to the 1 st day - $16.5 \%$ until the 11 th day $-4.5 \%$ and TDE also varied from $33.0 \%$ to $16.0 \%$, different for lactose in that on the 1 st day post-was $3.5 \%$ and on day $11,5.5 \%$.

The results of the present study were similar only in fat content, being different for protein, lactose and TDE, when compared to the study of PECKAKIEŁB et al. (2018), that evaluated the physicochemical composition of colostrum and milk from different species, for sheep were observed mean values of 10.6 $\%, 21.7 \%, 1.7 \%$ and $32.8 \%$ of fat, protein, lactose and TDE, respectively. The physical-chemical composition of colostrum is related to the species, breed and parity of the dams, being factors that directly influenced the values of colostrum and milk components.

Knowing the physico-chemical composition of Santa Inês sheep colostrum the producer can balance the diet offered to the herd and specially to ensure the survival and growth of lambs. The chemical composition and SCC of Santa Inês milk did not present significant difference $(\mathrm{P}>0.05)$ during refrigerated storage (Table 2).

The fat concentration, lactose and TDE were different from FAVA et al. (2014) that studying

Table 1 - Mean, maximum, minimum, standard deviation and standard error of fat, protein, casein, lactose, total dry extract (TDE), defatted dry extract (DDE) and (log) somatic cell count (SCC) of Santa Inês sheep colostrum.

\begin{tabular}{lcccrr}
\hline Parameters & Medium Value & Maximum Value & Minimum Value & Standard deviation & Standard error \\
\hline Fat (\%) & 10.92 & 14.79 & 7.69 & 2.03 & 0.34 \\
Protein (\%) & 6.23 & 10.49 & 4.47 & 0.37 & 0.19 \\
Casein (\%) & 5.31 & 9.03 & 3.77 & 1.90 & 1.08 \\
Lactose (\%) & 3.32 & 4.34 & 0.18 & 2.56 & 0.18 \\
TDE (\%) & 21.58 & 28.29 & 17.29 & 0.43 \\
DDE (\%) & 10.65 & 14.19 & 9.11 & 0.28 \\
SCC log & 6.06 & 6.73 & 4.81 & 0.45 \\
\hline
\end{tabular}

Ciência Rural, v.52, n.8, 2022. 
Table 2 - Mean values and standard error of the percentage of fat, protein, casein, lactose, total dry extract (EST), defatted dry extract (ESD) and $\log \log$ of SCC and log of total bacterial count (TBC) of Santa Inês sheep milk refrigerated for up to 240 hours.

\begin{tabular}{|c|c|c|c|c|c|c|c|c|}
\hline \multirow[t]{2}{*}{ Hours } & \multicolumn{8}{|c|}{ - } \\
\hline & Fat (\%) & Protein $(\%)$ & Casein $(\%)$ & Lactose $(\%)$ & TDE (\%) & DDE (\%) & SCC Log & TBC Log \\
\hline 0 & $2.95 \pm 0.13 \mathrm{a}$ & $5.20 \pm 0.03 a$ & $4.37 \pm 0.03 \mathrm{a}$ & $5.10 \pm 0.03 \mathrm{a}$ & $14.25 \pm 0.14 \mathrm{a}$ & $11.30 \pm 0.06 \mathrm{a}$ & $4.73 \pm 0.17 \mathrm{a}$ & $5.52 \pm 0.18 a$ \\
\hline 24 & $2.88 \pm 0.14 \mathrm{a}$ & $5.17 \pm 0.02 \mathrm{a}$ & $4.37 \pm 0.04 \mathrm{a}$ & $5.06 \pm 0.01 \mathrm{a}$ & $14.11 \pm 0.14 \mathrm{a}$ & $11.22 \pm 0.01 \mathrm{a}$ & $4.66 \pm 0.17 \mathrm{a}$ & $5.45 \pm 0.15 a$ \\
\hline 48 & $2.68 \pm 0.07 \mathrm{a}$ & $5.20 \pm 0.01 \mathrm{a}$ & $4.37 \pm 0.01 \mathrm{a}$ & $5.10 \pm 0.01 \mathrm{a}$ & $13.98 \pm 0.07 \mathrm{a}$ & $11.30 \pm 0.02 \mathrm{a}$ & $4.86 \pm 0.17 \mathrm{a}$ & $5.46 \pm 0.17 \mathrm{a}$ \\
\hline 72 & $2.69 \pm 0.06 \mathrm{a}$ & $5.19 \pm 0.01 \mathrm{a}$ & $4.35 \pm 0.03 \mathrm{a}$ & $5.11 \pm 0.01 \mathrm{a}$ & $13.99 \pm 0.07 \mathrm{a}$ & $11.30 \pm 0.01 \mathrm{a}$ & $4.88 \pm 0.17 \mathrm{a}$ & $5.52 \pm 0.18 \mathrm{a}$ \\
\hline 96 & $2.71 \pm 0.05 \mathrm{a}$ & $5.22 \pm 0.01 \mathrm{a}$ & $4.37 \pm 0.01 \mathrm{a}$ & $5.14 \pm 0.01 \mathrm{a}$ & $14.07 \pm 0.06 \mathrm{a}$ & $11.35 \pm 0.02 \mathrm{a}$ & $4.94 \pm 0.00 \mathrm{a}$ & $5.40 \pm 0.17 \mathrm{a}$ \\
\hline 120 & $2.74 \pm 0.13 \mathrm{a}$ & $5.20 \pm 0.01 \mathrm{a}$ & $4.35 \pm 0.01 \mathrm{a}$ & $5.12 \pm 0.01 \mathrm{a}$ & $14.06 \pm 0.13 \mathrm{a}$ & $11.32 \pm 0.01 \mathrm{a}$ & $4.93 \pm 0.00 \mathrm{a}$ & $5.37 \pm 0.17 \mathrm{a}$ \\
\hline 144 & $2.66 \pm 0.16 \mathrm{a}$ & $5.22 \pm 0.01 \mathrm{a}$ & $4.37 \pm 0.01 \mathrm{a}$ & $5.14 \pm 0.01 \mathrm{a}$ & $14.01 \pm 0.17 \mathrm{a}$ & $11.36 \pm 0.01 \mathrm{a}$ & $4.93 \pm 0.00 \mathrm{a}$ & $5.40 \pm 0.17 \mathrm{a}$ \\
\hline 168 & $2.73 \pm 0.10 \mathrm{a}$ & $5.22 \pm 0.01 \mathrm{a}$ & $4.36 \pm 0.01 \mathrm{a}$ & $5.14 \pm 0.01 \mathrm{a}$ & $14.08 \pm 0.11 \mathrm{a}$ & $11.35 \pm 0.02 \mathrm{a}$ & $4.92 \pm 0.00 \mathrm{a}$ & $5.42 \pm 0.17 \mathrm{a}$ \\
\hline 192 & $2.71 \pm 0.09 \mathrm{a}$ & $5.22 \pm 0.04 a$ & $4.37 \pm 0.01 \mathrm{a}$ & $5.14 \pm 0.01 \mathrm{a}$ & $14.07 \pm 0.08 \mathrm{a}$ & $11.36 \pm 0.01 \mathrm{a}$ & $4.89 \pm 0.00 \mathrm{a}$ & $5.48 \pm 0.18 \mathrm{a}$ \\
\hline 216 & $2.55 \pm 0.16 \mathrm{a}$ & $5.22 \pm 0.01 \mathrm{a}$ & $4.37 \pm 0.04 \mathrm{a}$ & $5.15 \pm 0.01 \mathrm{a}$ & $13.92 \pm 0.15 \mathrm{a}$ & $11.37 \pm 0.0 \mathrm{a}$ & $4.90 \pm 0.00 \mathrm{a}$ & $5.41 \pm 0.17 \mathrm{a}$ \\
\hline 240 & $2.81 \pm 0.22 \mathrm{a}$ & $5.06 \pm 0.16 \mathrm{a}$ & $4.24 \pm 0.14 \mathrm{a}$ & $5.05 \pm 0.09 a$ & $13.93 \pm 0.13 \mathrm{a}$ & $11.12 \pm 0.25^{\mathrm{a}}$ & $4.96 \pm 0.11 \mathrm{a}$ & $5.61 \pm 0.18 a$ \\
\hline
\end{tabular}

Different letters in the column differ from each other at the $5.0 \%$ level of significance by the Tukey test.

refrigerated and freezing Lacaune sheeps milk in different production months, they reported from May to September fat concentration of $8.58 \%, 8.02 \%$, $7.86 \%, 8.22 \%$ and $8.14 \%$, lactose of $4.40 \%, 4.49 \%$, $4.60 \%, 4.58 \%$ and $4.53 \%$ and TDE of $20.08 \%, 19.5$ $\%, 19.17 \%, 19.50 \%$ and $19.55 \%$ and similar values the protein for the same comparison period of 5.20 $\%, 5.26 \%, 5.25 \%, 5.10 \%$ and $5.20 \%$. Factors such as feeding, milking and refrigerated can influence the results obtained in the study for fat.

The SCC and TBC concentration did not show differences at all moments in which the milk was evaluated, corroborating with TAVARIA et al. (2006) that the refrigeration helps the conservation, since the enteric mesofauna does not have great values, and can become an effective option against certain types of microorganisms; conversely, refrigeration has an influence on the growth of yeasts that use acetic acid and act in the degradation of the protein and triglycerides (DEL POZO et al., 1988), contributing to the development specific flavors (DAHL et al., 2000). The refrigeration even prolonged period had no effect on the stored milk of the present study. Studies using the pasteurization process and use different types packaging for milk preservation, must still done to get more information about storage and milk quality effect.

Results of the SCC $\log$ and the TBC $\log$ of the study were similar to those observed by MARTÍNEZ et al. (2003) in sheep milk samples with preservative and without preservative Bronopol ${ }^{\circledR}$ and Azidiol ${ }^{\circledR}$. For refrigerated milk did not occur the addition of preservative was reported the $\log$ mean 5.46 , this being greater than the values reported for both the SCC and TBC in this study. For the milk with the Bronopol ${ }^{\circledR}$ preservative, it was found 5.53 and for Azidiol ${ }^{\circledR}, 5.46$ that is near the studied; however, regardless of the time analyzed, there was no differences $(P>0.05)$ regarding the storage time of sheep's milk.

Freezing storage of sheep's milk over bovine milk mainly due to the volume produced and seasonality, being important for industry and producers to search for technologies that help in the storage of product without loss added value and may be used in the manufacture of derivatives and sales of milk at different times of production. The values reported in the present study were $274,811 \mathrm{SC} / \mathrm{mL}$ and 3,603,167 CFU/mL.

Differing SCC and TBC values from the present study, GARNICA et al. (2011) studying about microbiological quality analysis of refrigerated milk from sheep revealed that sheep's milk stored at $4.0^{\circ} \mathrm{C}$ for up to 4 days, significantly increased concentration of mesophiles, psychrotrophs and coliforms over time, which fast milk processing is advisable. FAVA et al. (2014), observed that refrigeration sheep's milk for seven days affects the physical-chemical characteristics of the product. New studies with different temperatures should be performed to discover the possible implications for milk storage and microbiological study.

The table 3 shows the values referring to the physical- milk chemistry of Santa Inês sheep 
Table 3 - Mean values and standard error of the percentage of fat, protein, casein, lactose, total dry extract (TDE), defatted dry extract (DDE) and SCC $\log$ and total bacterial count (TBC) $\log$ of Santa Inês sheep milk Ines frozen for up to 70 days.

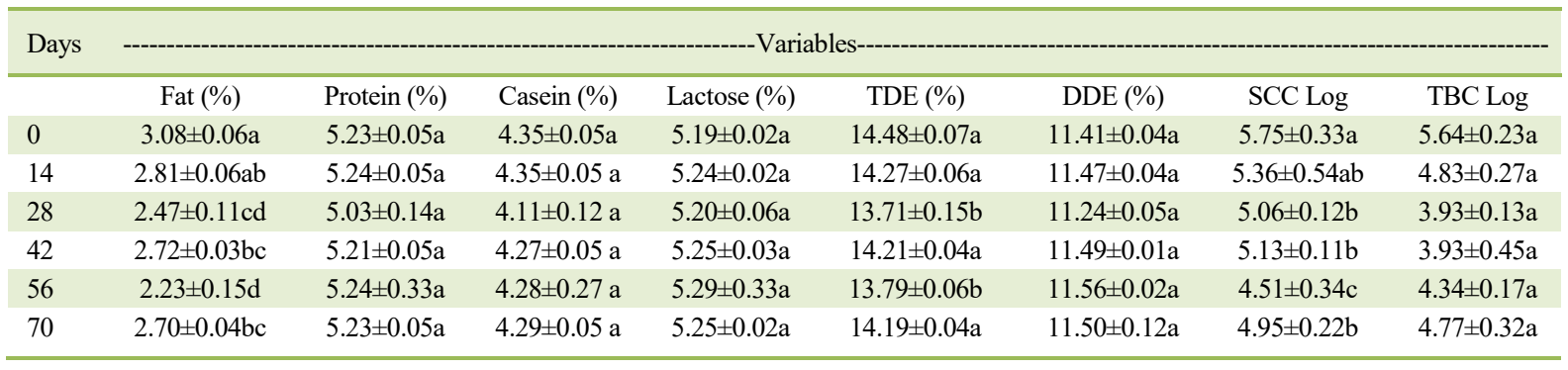

Different letters in the column differ from each other at the $5.0 \%$ level of significance by the Tukey test.

frozen for up to 70 days. Among the evaluated components the fat and DDE, were the only variables that presented differences.

The fat milk concentration of this study differed from the values observed by ZHANG et al. (2006), ovine milk freezing for up to six months, had their levels decreased, mainly for fat in which the values were: first month $(4.97 \%)$, the second month $(4.97 \%)$, the third month $(4.97 \%)$, the fourth month $(4.89 \%)$, the fifth month $(4.87 \%)$ and the sixth month $(4.85 \%)$, even with different values between the two studies it was possible to observe the concentrations in the frozen milk. The decrease in fat milk may be related to the formation of crystals ice, during freezing the which damages the fat globules.

The levels of protein, casein, lactose and dry extract defatted found by ZHANG et al. (2006) were different from those observed in the present study; however, in both cases the times that the milk was subjected to freezing had no influence on the percentage of components.

MARTÍNEZ et al. (2003) studied the effect of freezing on SCC sheep at different times (24 hours, 15 days, 30 days and 60 days) and obtained the SCC $\log$ results of 5.37; 5.37; 5.38 and 5.37, for each of the times studied, also evaluated the effect of slow melting as in the present study and the use of preservatives in milk and demonstrated the following values for the condition freezer with and without preservatives: for the condition of freezing with the the Bronopol ${ }^{\circledR}$ preservative, the mean was 5.54 differing from that study, for the Azidiol $^{\circledR}$ preservative, the mean observed was 5.33 and for the other samples where the preservative was not added the average was 5.51. The initial times for SCC and TBC did not differ $(\mathrm{P}>0.05)$.
The storage time of the milk must be pattern so that decrease the SCC variation in the frozen milk of sheep, being analyzed in milk up to three days after collection; however, milk should not be frozen (GONZALO et al. 1993). New research has been carried out and has shown great evolution regarding storage of sheep's milk and maintenance of the initial chemical composition.

In the milk of ewes frozen for up to seven days, the physico-chemical quality is not affected, becoming a solution for seasonality of milk production and low productivity, typical of the species (FAVA et al., 2014).

\section{CONCLUSION}

Chemical composition of sheep colostrum Santa Inês has a high concentration of proteins and fat, characterizing as an important source of energy for newborn lambs. Sheep's milk fresh can be stored under refrigeration between $4.0{ }^{\circ} \mathrm{C}$ and 7.0 hours in a period of up to 240 hours without changing the chemical composition and microbiological. Freezing sheep's milk for up to 70 days interfered the fat; however, did not differ the other constituents of the milk and there was no bacterial count.

\section{ACKNOWLEDGEMENTS}

To Fundação de Amparo à Pesquisa do Estado de Goiás (FAPEG) for the scholarship granted through the Announcement $\mathrm{n}^{\circ}$ 03/2017, Coordenação de Aperfeiçoamento de Pessoal de Nível Superior (CAPES), Conselho Nacional de Desenvolvimento Científico e Tecnológico (CNPq) (Process 302114/2018-1), Financiadora de Estudos e Projetos (FINEP), Universidade Federal de Goiás (UFG) and IF Goiano for the financial support for this research. 


\section{DECLARATION OF CONFLICT OF INTEREST}

The authors declare no conflict of interest. The founding sponsors had no role in the design of the study; in the collection, analyses, or interpretation of data; in the writing of the manuscript, and in the decision to publish the results.

\section{AUTHORS' CONTRIBUTIONS}

All authors contributed equally for the conception and writing of the manuscript. All authors critically revised the manuscript and approved of the final version.

\section{BIOETHICS AND BIOSSECURITY COMMITTEE APPROVAL}

The project was approved by the Committee of Ethics in the use of animals of the Instituto Federal Goiano with protocol $n^{\circ} 1825130717$.

\section{REFERENCES}

ALAIS, C., 1985. CIENCIA DE LA LECHE. Pincipios de técnica lechera, 1st ed. Nancy, França.

BARROS, N. N. et al. Growth traits of slaughter F1 lambs in northeast of Brazil. Pesquisa Agropecuária Brasileira, v.39, n.8, p.809-814, 2004. Avaliable from: <https://seer.sct.embrapa.br/ index.php/pab/article/view/6842>. Accessed: Nov. 08, 2020.

BOYAZOGLU, J. et al. Mediterranean dairy sheep and goat products and their quality: A critical review. Small Ruminant Research, v.40, n.1, p.1-11, 2001. Avaliable from: $<$ https://doi. org/10.1016/S0921-4488(00)00203-0>. Accessed: Nov. 08, 2020.

DAHL, S. et al. Relationships between flavour and microbiological profiles in Serra da Estrela cheese throughout ripening. International Dairy Journal, v. 10, n.4, p. 255-262, 2000. Avaliable from: $\quad<$ https://doi.org/10.1016/S0958-6946(00)00042-X>. Accessed: Nov. 08, 2020.

DEL POZO, B. F et al. Changes in the microflora of La Serena ewes' milk cheese during ripening. Journal of Dairy Research, v.55, n.3, p.449-455, 1988. Avaliable from: < https://doi.org/10.1017/ S0022029900028703>. Accessed: Nov. 08, 2020.

INTERNATIONAL STANDARD ISO 9622. Guidelines for the application of mid-, 2013. 2013.

FAVA, L. W., et al. Evaluation of physico-chemical characteristics of fresh, refrigerated and frozen Lacaune ewes' milk. Arquivo Brasileiro de Medicina Veterinária e Zootecnia, v.66, n.6, p.1924-1930, 2014. Avaliable from: $<$ https://doi.org/10.1590/16787675>. Accessed: Nov. 08, 2020.

FERREIRA, D. F., 2015. Sisvar [WWW Document]. Avaliable from: $\quad<$ https://doi.org/http://dx.doi.org/10.1590/S141370542014000200001>. Accessed: Nov. 08, 2020.

FERREIRA, M. I. C. et al. Milk production and composition of Santa Ines and Lacaune x Santa Ines crossbred ewes and performance of their lambs. Arquivo Brasileiro de Medicina Veterinária e Zootecnia, v.63, n.2, p.530-533, 2011. Avaliable from: $\quad<$ https://doi.org/10.1590/S0102-09352011000200040>. Accessed: Nov. 08, 2020.

GARNICA, M. L. et al. Influence of storage and preservation on microbiological quality of silo ovine milk. Journal of Dairy Science, v.94, n.4, p.1922-1927, 2011. Avaliable from: <https:// doi.org/10.3168/jds.2010-3787>. Accessed: Nov. 08, 2020.

GONZALO, C., et al. Use of the Fossomatic method to determine somatic cell counts in sheep milk. Journal of Dairy Science, v.76, n.1, p.115-119, 1993. Avaliable from: <https://doi.org/10.3168/jds. s0022-0302(93)77330-0>. Accessed: Nov. 08, 2020.

HADJIPANAYIOTOU, M. Composition of ewe, goat and cow milk and of colostrum of ewes and goats. Small Ruminant Research, v.18, n.3, p.255-262, 1995. Avaliable from: <https://doi. org/10.1016/0921-4488(95)00697-3>. Accessed: Nov. 08, 2020.

HERNÁNDEZ-CASTELLANO, L. E. et al. A proteomics study of colostrum and milk from the two major small ruminant dairy breeds from the Canary Islands: a bovine milk comparison perspective. Jornal Dairy Research, v.83, p.366-374, 2016. Avaliable from: $<$ https://doi.org/10.1017/s0022029916000273>. Accessed: Nov. $08,2020$.

INTERNATIONAL STANDARD ISO 9622. Guidelines for the application of mid-, 2013. 2013.

KATILI, L. M. et al. Chemicophysical and microbiological aspects of cheese made of a mixed coagulation, ripened by mould using slow or fast frozen goat's milk and slow or fast frozen curd. Food Science and Technology, v.26, n.4, p.740-743, 2006. Avaliable from: $\quad<$ https://doi.org/10.1590/s0101-20612006000400004>. Accessed: Nov. 08, 2020.

KUMAR, H., KUMAR, S., KUMAR, K. Chemical and Immunological Quality of Sheep Colostrum : Effect of Breed. Human Health and Nutrition. 48-53, 2017. ISBN: 978-81932755-7-3. Accessed: Nov. 08, 2020.

MARTÍNEZ, J. R. et al. Effect of freezing on Fossomatic cell counting in ewe milk. Journal of Dairy Science, v.86, n.8, p.25832587, 2003. Avaliable from: <https://doi.org/10.3168/jds.s00220302(03)73853-3>. Accessed: Nov. 08, 2020

MCKUSICK, B. C. et al. Effect of milking interval on alveolar versus cisternal milk accumulation and milk production and composition in dairy ewes. Journal of Dairy Science, v.85, n.9, p.2197-2206, 2002. Journal Dairy Science, v.85, pag.21972206. Avaliable from: <https://doi.org/10.3168/jds.s00220302(02)74299-9>. Accessed: Nov. 08, 2020.

MIRANDA, G. et al. Origine, nature et incidences technologiques de la protéolyse dans le lait. Le Lait, v.66, n.1, p.1-18, 1986. Avaliable from: $<$ https://doi.org/10.1051/lait:198611 >. Accessed: Nov. 08, 2020.

MOHAPATRA, A., et al. Sheep milk: A pertinent functional food. Small Ruminant Research, v.181, p.6-11, 2019. Avaliable from: $<$ https://doi.org/10.1016/j.smallrumres.2019.10.002>. Accessed: Nov. 08,2020

PATTINSON, S. E. et al. Changes in the secretion rate and production of colostrum by ewes over the first $24 \mathrm{~h}$ post partum. Animal Science, v.61, n.1, p.63-68, 1995. Avaliable from: $<$ https:// doi.org/10.1017/S1357729800013527>. Accessed: Nov. 08, 2020. 
PECKA-KIEŁB, E. et al. Influence of nutrition on the quality of colostrum and milk of ruminants. Mljekarstvo: časopis za unaprjeđenje proizvodnje i prerade mlijeka, v.68, n.3, p.169-181, 2018. Avaliable from: <https://doi.org/10.15567/ mljekarstvo.2018.0302>. Accessed: Nov. 08, 2020.

PORCIONATO, M. A. et al. Effect of the boil, refrigeration or freezing on the quality of raw milk. Revista Acadêmica Ciência Animal, v.6, n.4, p.511-517, 2008. Avaliable from: <https://doi. org/10.7213/cienciaanimal.v6i4.11642>. Accessed: Nov. 08, 2020.

RAUPRICH, A. B. et al. Influence of feeding different amounts of first colostrum on metabolic, endocrine, and health status and on growth performance in neonatal calves. Journal of Animal Science, v.78, n.4, p.896-908, 2000. Avaliable from: $<$ https://doi. org/10.2527/2000.784896x>. Accessed: Nov. 08, 2020.

REGO NETO, A. A. et al. Population genetic structure of Santa Inês sheep in Brazil. Tropical animal health and production, v.50, n.3, p.503-508, 2018. Avaliable from: <https://doi.org/10.1007/ s11250-017-1459-5>. Accessed: Nov. 08, 2020.
SOUZA, A. C. K. O et al. Production, chemical composition and physical characteristics of sheep milk in corriedale breed. Current Agricultural Science and Technology, v.11, n.1, 2005. Avaliable from: $<$ https://doi.org/10.18539/cast.v11i1.1173>. Accessed: Nov. 08, 2020.

TAVARIA, F. K. et al. Effect of dairy farm and milk refrigeration on microbiological and microstructural characteristics of matured Serra da Estrela cheese. International Dairy Journal, v.16, n.8, p.895-902, 2006. Avaliable from: <https://doi.org/10.1016/j. idairyj.2005.08.010>. Accessed: Nov. 08, 2020.

VERÍSSIMO, C. J. et al. Heat tolerance of Santa Ines ewes with light and dark colored pelage. Revista Brasileira de Saúde e Produção Animal, v.10, n.1, 2009. Avaliable from: <https://portalseer.ufba.br/ index.php/rbspa/article/view/39814>. Accessed: Nov. 08, 2020.

ZHANG, R. H., et al. Effects of freezing on composition and fatty acid profiles of sheep milk and cheese. Small Ruminant Research, v.64, n.3, pág. 203-210, 2006. Available from: <https:// doi.org/10.1016/j.smallrumres.2>. Accessed: Nov. 08, 2020. 